\title{
Degradacja mikrostruktury stali 13CrMo4-5 pracującej w warunkach pełzania w kontekście trwałości konstrukcji kotłowych
}

\author{
Degradation of 13CrMo4-5 steel microstructure \\ working under creep conditions \\ in the context of boiler components durability
}

\section{Streszczenie}

Artykuł zawiera modelowe obrazy kolejnych etapów degradacji mikrostruktury stali 13CrMo4-5 (15HM, Wr nr.: 1.7335) pracującej w warunkach pełzania charakterystycznego dla części ciśnieniowej kotła i innej armatury energetycznej. Na podstawie uzyskanych wyników, dla badanego materiału zaproponowano klasy mikrostruktury w zależności od jej stanu, w tym również stopnia rozwoju procesów wydzieleniowych w powiązaniu ze stopniem wyczerpania.

W postaci graficznej przedstawiono odniesienie klas mikrostruktury do stopnia wyczerpania. Dokonano tego na podstawie oceny zmian w strukturze to jest: stopnia rozpadu poszczególnych faz, stopnia rozwoju procesów wydzieleniowych oraz stopnia rozwoju wewnętrznych uszkodzeń. Zestawiono w tabeli okresy dopuszczenia do dalszej eksploatacji w zależności od klasy struktury i odpowiadającego stopnia wyczerpania.

Słowa kluczowe: pełzanie; stal odporna na pełzanie; trwałość

\begin{abstract}
The article contains the model images of the 13CrMo4-5 $(15 \mathrm{HM})$ steel microstructure degradation working in creep conditions of pressure zone for the boiler. The material being tested is given class structure according to the state of the microstructure, including: the degree of development of the processes of precipitation in relation to the degree of exhaustion. In graphical form shows the microstructure of a reference class to the degree of exhaustion, made on the basis of changes in the structure of it is: the degree of disintegration of the individual phases and level of precipitation processes and the degree of development of internal damage. The tables summarize the proposed periods of admission to further exploitation depending on the class structure and the corresponding degree of exhaustion.
\end{abstract}

Keywords: creep; heat-resistant pressure-vessel steels; creep resistant steel; pressure vessel steel; sustainability

\section{Wstęp}

Przedmiotem opracowania jest obrazowanie $\mathrm{i}$ analiza degradacji mikrostruktury i wynikającej z tego zmiany właściwości materiału. Pozwala to na ocenę stanu elementów ciśnieniowych kotłów i innej armatury energetycznej pracujących w warunkach pełzania. Tego rodzaju podejście daje możliwość szacowania oraz wyznaczenia ich trwałości eksploatacyjnej. W procesie diagnostyki eksploatowanego materiału i prognozowania bezpiecznego czasu dalszej eksploatacji elementów kotłów i rurociągów pracujących w warunkach pełzania stosowane są metody, które można podzielić na dwie grupy $[1 \div 5]$ : a) oparte na obliczeniach, bazujących na podstawie zarejestrowanych wartości temperatury i ciśnienia roboczego przy wykorzystaniu charakterystyki wytrzymałości na pełzanie materiałów w stanie wyjściowym, zawartych w normach dla wyrobów hutniczych (np. metoda ułamków trwałości Robinsona),

b) obejmujące pomiary właściwości geometrycznych i odkształceń trwałych oraz badania nieniszczące i niszczące w celu oceny stanu materiału elementów po eksploatacji. W praktyce inżynierskiej stosowane są metody kwalifikowane do obu grup, przy czym metody obliczeniowe stosuje

Mgr inż. Adam Ogrodnik - Urząd Dozoru Technicznego.

Autor korespondencyjny/Corresponding author. adam.ogrodnik@udt.gov.pl 
się zazwyczaj w prognozowaniu czasu i warunków dalszej eksploatacji jako główny element analizy ekonomicznej, w podejmowaniu decyzji o przystąpieniu do badań diagno-

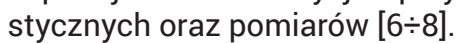

W opracowaniu przyjęto, że wyłącznie pomiary oraz badania nieniszczące i niszczące uzupełnione wynikami obliczeń przeprowadzonych dla rzeczywistych warunków pracy stanowią podstawę wiarygodnej oceny stanu elementów pracujących w warunkach pełzania. Umożliwia to szacowanie/wyznaczenie czasu dalszej bezpiecznej eksploatacji.

Niniejszy artykuł jest częścią szerszej pracy ukierunkowanej na opracowanie jednolitej metodologii oceny stanu eksploatowanego materiału w kontekście pozostałej bezpiecznej trwałości eksploatacyjnej elementów części ciśnieniowej kotłów i rurociągów pracujących w warunkach pełzania. Zaproponowany tryb postępowania wykorzystuje współcześnie dostępne narzędzia i metody badawcze zweryfikowane $w$ praktyce na podstawie doświadczeń opartych o wieloletnią diagnostykę materiałową. Opracowaną metodologię przedstawiono $\mathrm{w}$ formie algorytmu przedstawiającego zalecany sposób postępowania przy diagnozowaniu i wyznaczeniu czasu dalszej bezpiecznej eksploatacji elementów kotłów i rurociągów, pracujących w warunkach pełzania.

Stale przeznaczone do pracy w podwyższonej temperaturze w warunkach pełzania, stosowane w energetyce stanowią liczną grupę. Różnią się między sobą składem chemicznym, strukturą po obróbce cieplnej i zastosowaniem. Stale niskostopowe przeznaczone są w zależności od składu chemicznego, do pracy w temperaturze $480 \div 590{ }^{\circ} \mathrm{C}$, natomiast wysokochromowe stale o strukturze martenzytycznej przeznaczone są do pracy w temperaturze do $620^{\circ} \mathrm{C}$.

Stal stosowana na elementy kotłów i rurociągów powinna charakteryzować się $[6 \div 10]$ :

- stabilnymi w czasie długotrwałej eksploatacji właściwościami wytrzymałościowymi w podwyższonej temperaturze [11],

- niską skłonnością do wzrostu kruchości (obniżenia udarności, wzrostu temperatury przejścia w stan kruchy) w warunkach pracy [12],

- wysoką granicą plastyczności i wytrzymałością na rozciąganie,

- stabilną mikrostrukturą w czasie długotrwałej eksploatacji,

- korzystnymi właściwościami fizycznymi, tj. możliwie małym współczynnikiem rozszerzalności liniowej i dużym współczynnikiem przewodzenia ciepła,
- odpowiednią żarowytrzymałością i żaroodpornością,

- odpowiednią odpornością na zmęczenie cieplne i cieplnomechaniczne podczas eksploatacji, a szczególnie odpornością na zmęczenie niskocyklowe [13],

- odpowiednimi właściwościami technologicznymi, takimi jak: dobra spawalność, podatność do przeróbki plastycznej i obróbki cieplnej.

Niniejsze opracowanie dotyczy niskostopowej stali o strukturze ferrytyczno-perlitycznej typu 13CrMo4-5 (15HM, 1.7335) eksploatowanej powyżej 100000 h w warunkach pełzania.

\section{Wyniki badań}

Opracowanie zawiera modelowe obrazy degradacji mikrostruktury stali 13CrMo4-5 pracującej w warunkach pełzania w części ciśnieniowej kotła energetycznego. Przyjęty sposób jest analogiczny do metodologii zaproponowanej w pracy [14], co umożliwia porównanie obu materiałów według takich samych kryteriów oceny. Modele degradacji mikrostruktury zamieszczono na rysunku 2. Dla przedmiotowego materiału podano klasy struktury w zależności od stanu jej podstawowych składników strukturalnych i stopnia rozwoju procesów wydzieleniowych w powiązaniu ze stopniem wyczerpania. W postaci graficznej przedstawiono odniesienie klas mikrostruktury do stopnia wyczerpania, dokonane na podstawie oceny następujących zmian w strukturze: stopnia rozpadu poszczególnych faz, stopnia rozwoju procesów wydzieleniowych oraz stopnia rozwoju wewnętrznych uszkodzeń (rys. 1.). Stopień wyczerpania będący miarą przydatności elementu do dalszej pracy, w praktyce, definiowany jest jako stosunek czasu eksploatacji $t_{e}$ do czasu $t_{r}$ po którym następuje zniszczenie materiału dla roboczych parametrów eksploatacyjnych. Uszkodzenie w wyniku pełzania to nieodwracalne zmiany w strukturze, spowodowane przez równoczesne oddziaływanie temperatury i naprężenia mechanicznego w długotrwałym czasie. Stopień uszkodzenia może być określony eksperymentalnie metodami metalograficznymi. Wyczerpywanie się materiału jest spowodowane między innymi przez powstawanie i rozwijanie się uszkodzeń wewnętrznych $w$ metalu poddanym pełzaniu w przypadku, gdy $\dot{\omega} \neq 0$, a $\dot{S}_{i}=0$ ( $\dot{\omega}$ - prędkość propagacji uszkodzeń, $\dot{S}_{i}-$ prędkość zmian w strukturze).
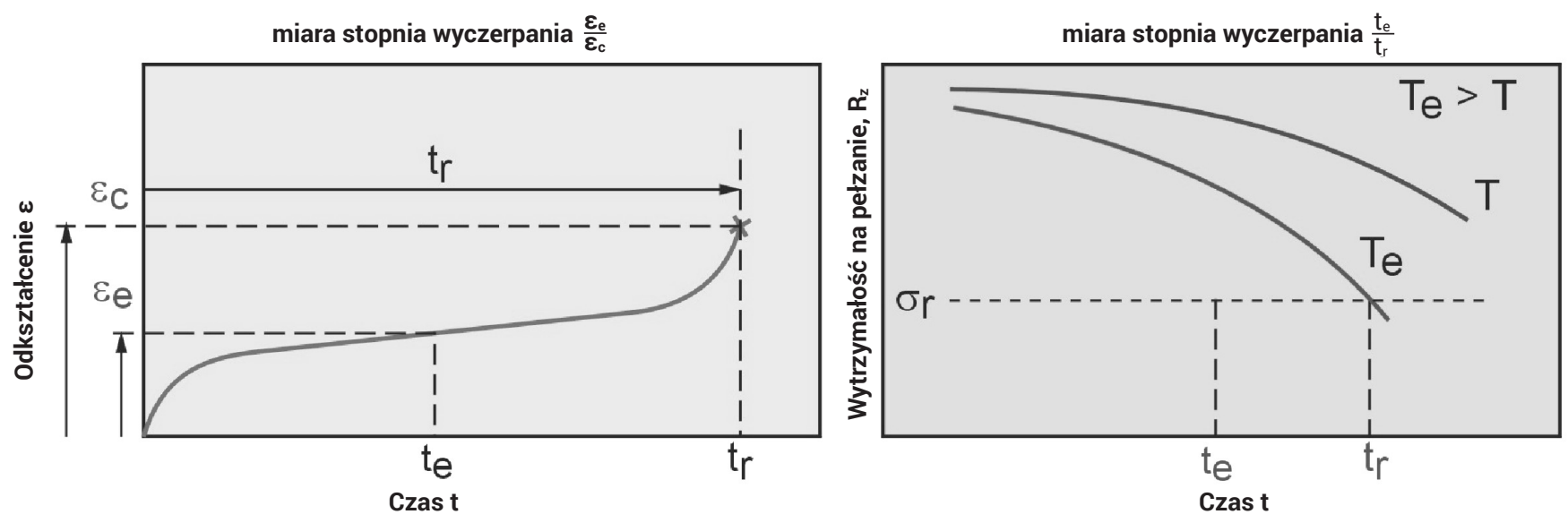

Rys. 1. Graficzne ujęcie wyczerpania materiału, definiowane w oparciu o: a) stosunek odkształcenia $\varepsilon_{\mathrm{e}} / \boldsymbol{\varepsilon}_{\mathrm{c}}$ lub b) stosunek czasu $\mathrm{t}_{\mathrm{e}} / \mathrm{t}_{\mathrm{r}}$ gdzie: $\varepsilon_{\mathrm{e}}$ - trwałe odkształcenie odpowiadające czasowi eksploatacji $\mathrm{t}_{\mathrm{e}}, \boldsymbol{\varepsilon}_{\mathrm{c}}$ - całkowite trwałe odkształcenie odpowiadające czasowi do zniszczenia $t_{r}, t_{e}$ - czas eksploatacji, $t_{r}-$ czas do zniszczenia

Fig. 1. Graphic depiction of exhaustion, defined on the basis of: a) deformation ratio $\varepsilon_{e} / \varepsilon_{c}$ or b) ratio of time $t_{e} / t_{r}$ where: $\varepsilon_{e}-$ permanent deformation corresponding to the time of exploitation $t_{e}, \varepsilon_{c}-$ total permanent deformation corresponding to time to destruction $t_{r}, t_{e}-$ operating time, $\mathrm{t}_{\mathrm{r}}$ - time to destruction 
W praktyce zwykle oba wymienione procesy (wyczerpanie i uszkodzenie) przebiegają równolegle, a tylko jeden z nich jest dominującym w zależności od stadium pełzania. W zależności od stadium pełzania różny jest stopień wyczerpania materiału i różne nasilenie uszkodzeń, od pojedynczych pustek poprzez szczeliny międzykrystaliczne do pęknięć.

Ponadto w postaci tabelarycznej zestawiono zaproponowane okresy dopuszczenia do dalszej eksploatacji w zależności od klasy struktury i odpowiadającego jej stopnia wyczerpania (tabl. I).
Dla przedmiotowej stali pokazano przykłady oceny stanu mikrostruktury, obserwacje mikrostruktury przeprowadzane na mikroskopie świetlnym oraz skaningowym mikroskopie elektronowym. Badania wykonano z wykorzystaniem zgładów metalograficznych, a także replik matrycowych pobieranych bezpośrednio z obiektów przemysłowych. Przykłady te obejmują stan materiału po wielogodzinnej eksploatacji bez uszkodzeń wewnętrznych w wyniku procesu pełzania (tabl. II).

Tablica I. Okres dopuszczenia do dalszej eksploatacji w zależności od klasy struktury niskostopowej stali ferrytyczno-perlitycznej 13CrMo4-5 (15HM) pracującej w warunkach pełzania

Table I. Time of exploitation depended on microstructure class of low alloy $13 \mathrm{CrMo} 4-5$ steel operating in creep condition

Stal chromowo - molibdenowa 13CrMo4-5 (15HM), ferrytyczno-perlityczna

\begin{tabular}{|c|c|c|c|c|c|}
\hline \multirow[t]{2}{*}{ Stan struktury } & \multirow[t]{2}{*}{$\begin{array}{l}\text { Skład fazowy } \\
\text { wydzieleń }\end{array}$} & \multirow[t]{2}{*}{$\begin{array}{c}\text { Klasa } \\
\text { struktury }\end{array}$} & \multirow{2}{*}{$\begin{array}{c}\text { Stopień } \\
\text { wyczerpania } \\
t_{\mathrm{e}} / \mathrm{t}_{\mathrm{r}}\end{array}$} & \multicolumn{2}{|c|}{$\begin{array}{c}\text { Czas dopuszczenia } \\
\text { do dalszej eksploatacji [h] } \\
\text { w zależności } \\
\text { od dotychczasowego okresu } \\
\text { pracy }\end{array}$} \\
\hline & & & & $\begin{array}{l}\text { od } 100000 \\
\text { do } 150000 \mathrm{~h}\end{array}$ & $\begin{array}{c}\text { powyżej } \\
150000 \mathrm{~h}\end{array}$ \\
\hline \multirow{3}{*}{$\begin{array}{l}\text { Struktura stanu wyjściowego lub niewiele } \\
\text { odbiegająca } \\
\text { od stanu wyjściowego - perlit z ferrytem: } \\
\text { - płytki cementytu w perlicie, } \\
\text { - pojedyncze lub nieliczne drobne } \\
\text { wydzielenia węglików w objętości ziaren } \\
\quad \text { ferrytu, } \\
\text { - pojedyncze lub nieliczne wydzielenia } \\
\text { węglików w bainicie. }\end{array}$} & \multirow{2}{*}{$\mathrm{M}_{3} \mathrm{C}+\left(\mathrm{M}_{2} \mathrm{C}\right)$} & 0 & 0 & \multirow{4}{*}{$\begin{array}{l}\text { maks. } \\
60000\end{array}$} & \multirow{4}{*}{$\begin{array}{l}\text { maks. } \\
40000\end{array}$} \\
\hline & & $0 / 1$ & do 0,2 & & \\
\hline & $\begin{array}{c}\mathrm{M}_{3} \mathrm{C} \text { (zmniejszenie } \\
\text { udziału) }+\mathrm{M}_{2} \mathrm{C} \\
+\mathrm{M}_{23} \mathrm{C}_{6}(\text { wzrost } \\
\text { udziału })+\left(\mathrm{M}_{7} \mathrm{C}_{3}\right)\end{array}$ & 1 & $0,2 \div 0,3$ & & \\
\hline $\begin{array}{l}\text { Nieznaczny lub częściowy rozpad perlitu: } \\
\text { - } \quad \text { fragmentacja płytek cementytu w perlicie, } \\
\text { - koagulacja wydzieleń węglików w obsza- } \\
\text { rach perlitu, } \\
\text { - drobne wydzielenia węglików na granicach } \\
\text { ziaren ferrytu, } \\
\text { - koagulacja wydzieleń w obszarach bainitu. }\end{array}$ & $\begin{array}{c}\mathrm{M}_{23} \mathrm{C}_{6} \text { (wzrost } \\
\text { udziału) }+\mathrm{M}_{2} \mathrm{C} \\
+\mathrm{M}_{3} \mathrm{C} \text { (obniżanie się } \\
\text { udziału) }+\mathrm{M}_{7} \mathrm{C}_{3}\end{array}$ & 2 & $0,3 \div 0,4$ & & \\
\hline \multirow{2}{*}{$\begin{array}{l}\text { Znaczy rozpad perlitu: } \\
\text { - postępujący proces koagulacji węglików, } \\
\text { - znaczna ilość sferoidalnych wydzieleń } \\
\text { w obszarach perlitu } \\
\text { - pierwsze łańcuszki węglików na granicach } \\
\text { ziarn ferrytu, } \\
\text { - wzrost wielkości występujących niektó- } \\
\text { rych typów węglików }\end{array}$} & $\begin{array}{c}\mathrm{M}_{23} \mathrm{C}_{6} \text { (dalszy wzrost } \\
\text { udziału) }+\mathrm{M}_{2} \mathrm{C}+\mathrm{M}_{3} \mathrm{C} \\
\text { (dalsze obniżanie się } \\
\text { udziału) }+\mathrm{M}_{7} \mathrm{C}_{3}\end{array}$ & 3 & $0,4 \div 0,5$ & $\begin{array}{l}\text { maks. } \\
40000\end{array}$ & \multirow{2}{*}{ DT } \\
\hline & $\mathrm{M}_{23} \mathrm{C}_{6}+\mathrm{M}_{7} \mathrm{C}_{3}+\mathrm{M}_{6} \mathrm{C}$ & $3 / 4$ & $0,5 \div 0,6$ & $\begin{array}{l}\text { maks. } \\
30000\end{array}$ & \\
\hline $\begin{array}{l}\text { Całkowity zanik obszarów perlitycznych: } \\
\text { - ferryt z węglikami, } \\
\text { - koagulacja i koalescencja węglików } \\
\text { w ferrycie, } \\
\text { - węgliki równomiernie rozmieszczone } \\
\text { w strukturze, } \\
\text { - dalszy znaczny wzrost niektórych typów } \\
\text { węglików, } \\
\text { - tańcuszki węglików na granicy ziaren } \\
\text { ferrytu } \\
\text { (siatki węglików) } \\
\text { - możliwość występowania pustek }\end{array}$ & $\begin{array}{c}\mathrm{M}_{6} \mathrm{C} \text { (wzrost udziału) } \\
+\mathrm{M}_{23} \mathrm{C}_{6}+\mathrm{M}_{7} \mathrm{C}_{3} \\
\text { (obniżanie się } \\
\text { udziału) }\end{array}$ & 4 & $>0,6$ & DT & DT \\
\hline
\end{tabular}




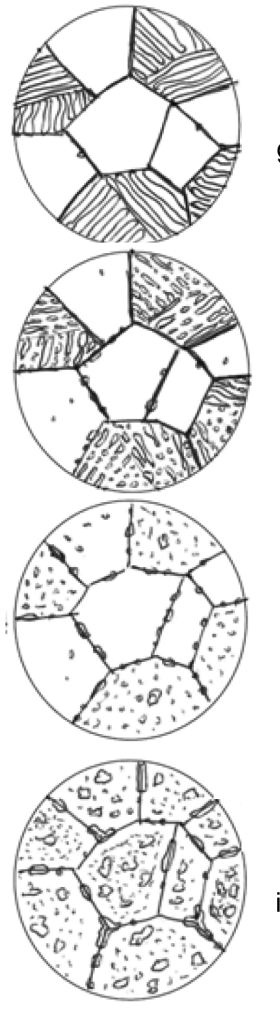

KIasa 0

Płytki cementytu w perlicie, pojedyncze wydzielenia głównie na granicach, również w ziarnach ferrytu

Klasa 1,2

Rozdrobnienie płytek cementytu w perlicie z częściową koagulacją węglików, wydzielenia na granicach ziaren ferrytu lokalnie tworzące kierunkowe skupiska

Klasa 3

Zupełna koagulacja wydzieleń w perlicie, łańcuszki wydzieleń na granicach ziaren, nieliczne drobne wydzielenia wewnatrz ziaren ferrytu

Klasa 4

ferryt z wydzieleniami różnej wielkości, równomiernie rozmieszczonymi wewnątrz i łańcuszkami zróżnicowanej wielkości na granicach ziaren

Rys. 2. Modele degradacji struktury ferrytyczno-perlitycznej stali 13CrMo4-5 (15HM) w wyniku pełzania. Klasy struktury w zależności od stanu jej podstawowych składników i stopnia rozwoju procesów wydzieleniowych w powiązaniu ze stopniem wyczerpania bez wewnętrz nych uszkodzeń

Fig. 2. The models of ferritic-pearlitic structure degradation in 13CrMo4-5 steel as a result of creeping process. Structure classes depended on state of microstructure and level of damage development

\begin{tabular}{|c|c|c|c|c|}
\hline \multicolumn{5}{|c|}{$\begin{array}{l}\text { KLASY SKŁADOWYCH PROCESÓW W STRUKTURZE } \\
\text { STALI 13CrMo4-5 }\end{array}$} \\
\hline \multirow{2}{*}{$\begin{array}{l}\text { Klasa } \\
\text { zmian } \\
\text { perlitu }\end{array}$} & \multicolumn{2}{|c|}{ Procesy wydzieleniowe } & \multirow{2}{*}{\multicolumn{2}{|c|}{$\begin{array}{l}\text { Procesy } \\
\text { uszko- } \\
\text { dzenia }\end{array}$}} \\
\hline & Klasa & $\begin{array}{c}\text { Typ } \\
\text { węglików }\end{array}$ & & \\
\hline 1 & 2 & 3 & & 4 \\
\hline \multirow{4}{*}{ II } & \multirow{4}{*}{$b$} & \multirow{4}{*}{$\begin{array}{l}\mathrm{M}_{6} \mathrm{C} \uparrow+ \\
\mathrm{M}_{23} \mathrm{C} \downarrow+ \\
\left(\mathrm{M}_{7} \mathrm{C}_{3} \downarrow\right)\end{array}$} & \multicolumn{2}{|c|}{ D } \\
\hline & & & \multicolumn{2}{|c|}{ C } \\
\hline & & & \multirow{2}{*}{ B } & B2 \\
\hline & & & & B1 \\
\hline \multirow{2}{*}{$\mathrm{I} / \mathrm{II}$} & \multirow{2}{*}{$a / b$} & \multirow{2}{*}{$\begin{array}{c}\mathrm{M}_{23} \mathrm{C}_{6}+\mathrm{M}_{7} \mathrm{C}_{3} \\
+\mathrm{M}_{6} \mathrm{C}\end{array}$} & \multicolumn{2}{|c|}{ A } \\
\hline & & & \multicolumn{2}{|c|}{ OIA } \\
\hline I & a & $\begin{array}{c}M_{23} \mathrm{C} \uparrow+\mathrm{M}_{2} \mathrm{C} \\
+\mathrm{M}_{3} \mathrm{C} \downarrow+\left(\mathrm{M}_{7} \mathrm{C}_{3}\right)\end{array}$ & \multirow{2}{*}{\multicolumn{2}{|c|}{$\mathbf{0}$}} \\
\hline 0 & $\mathrm{O}$ & $\begin{array}{c}\mathrm{M}_{3} \mathrm{C}+\mathrm{M}_{2} \mathrm{C} \\
+\mathrm{M}_{23} \mathrm{C}_{6}+\left(\mathrm{M}_{7} \mathrm{C}_{3}\right) \\
\mathrm{M}_{3} \mathrm{C}+\left(\mathrm{M}_{2} \mathrm{C}\right)\end{array}$ & & \\
\hline
\end{tabular}
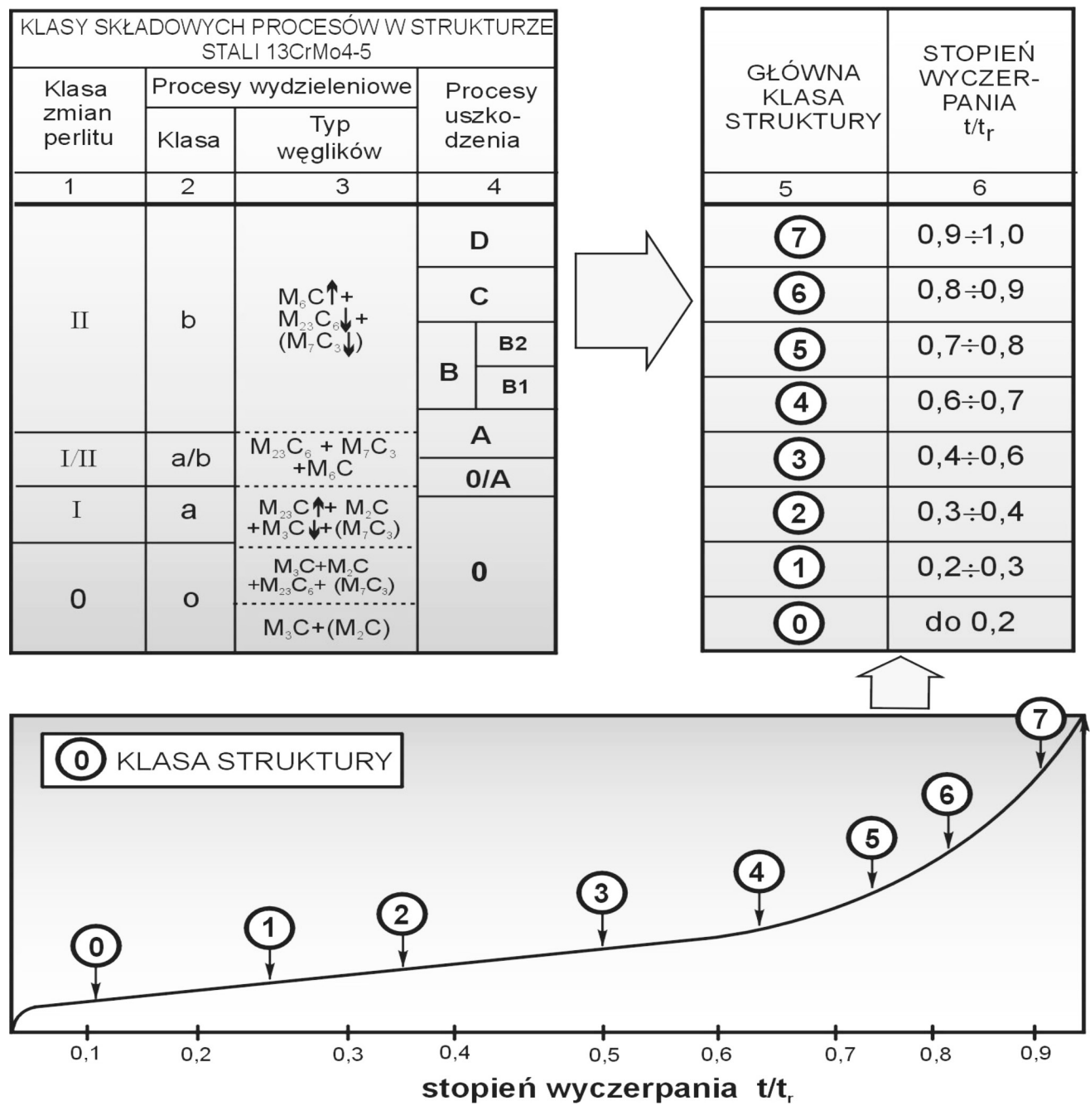

Rys. 3. Klasa mikrostruktury w odniesieniu do stopnia wyczerpania na podstawie oceny zmian w strukturze: stopnia rozpadu obszarów perlitycznych, stopnia rozwoju procesów wydzieleniowych oraz stopnia rozwoju wewnętrznych uszkodzeń niskostopowej $\omega$ stali ferrytyczno-perlitycz. pracującej w warunkach pełzania.

Fig. 3. Class of microstructure depended on state of material exhausting based on changes in microstructure assessment: ????????????? 
Tablica II. Przykłady oceny stanu mikrostruktury niskostopowej stali ferrytyczno-perlitycznej 13CrMo4-5 (15HM) po długotrwałej eksploatacji w warunkach pełzania

Table II. Examples of the microstructure evaluation of ferritic-pearlitic low alloy steel -13CrMo4-5 (15HM) after long-term operation in creep condition

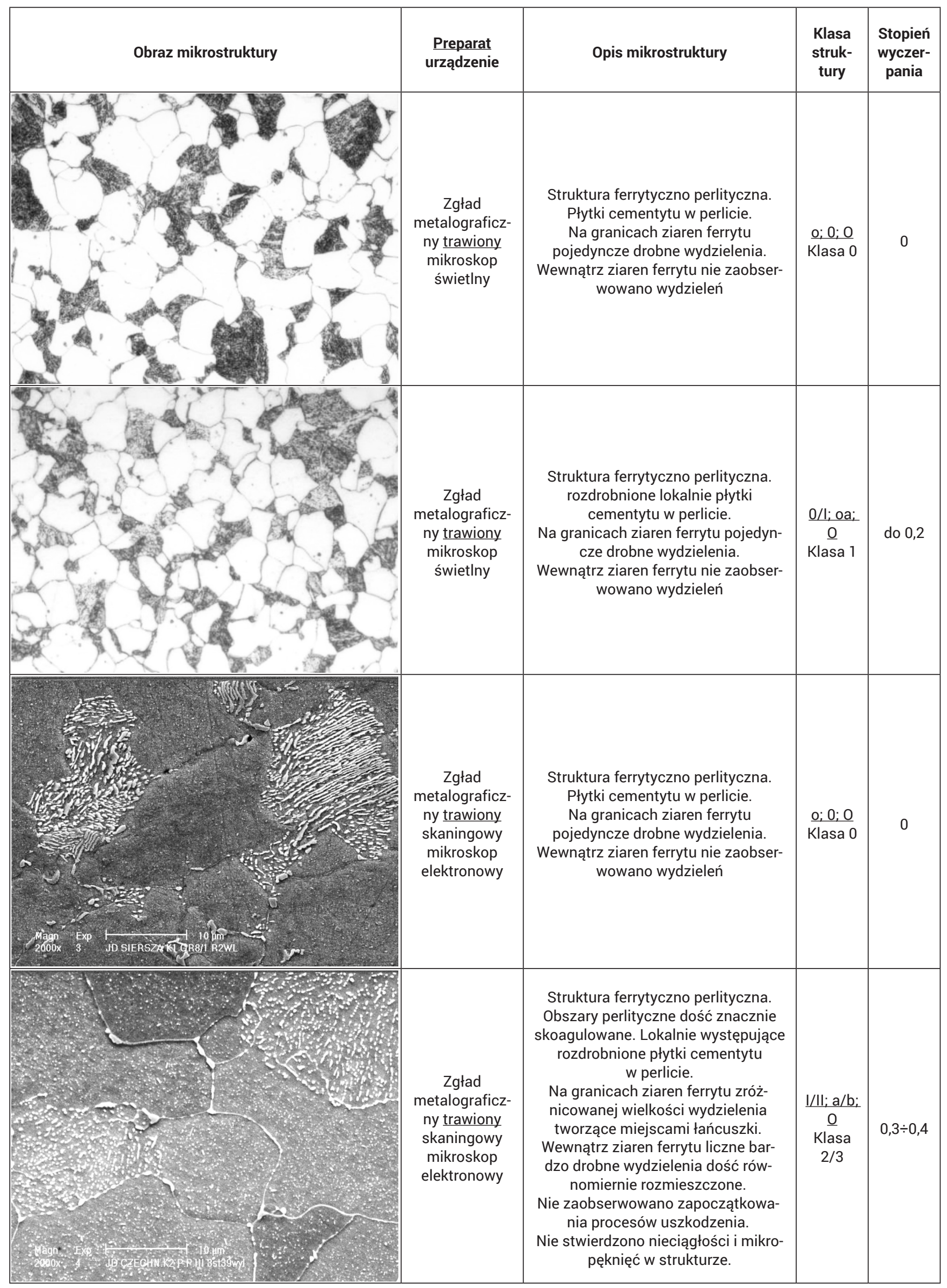




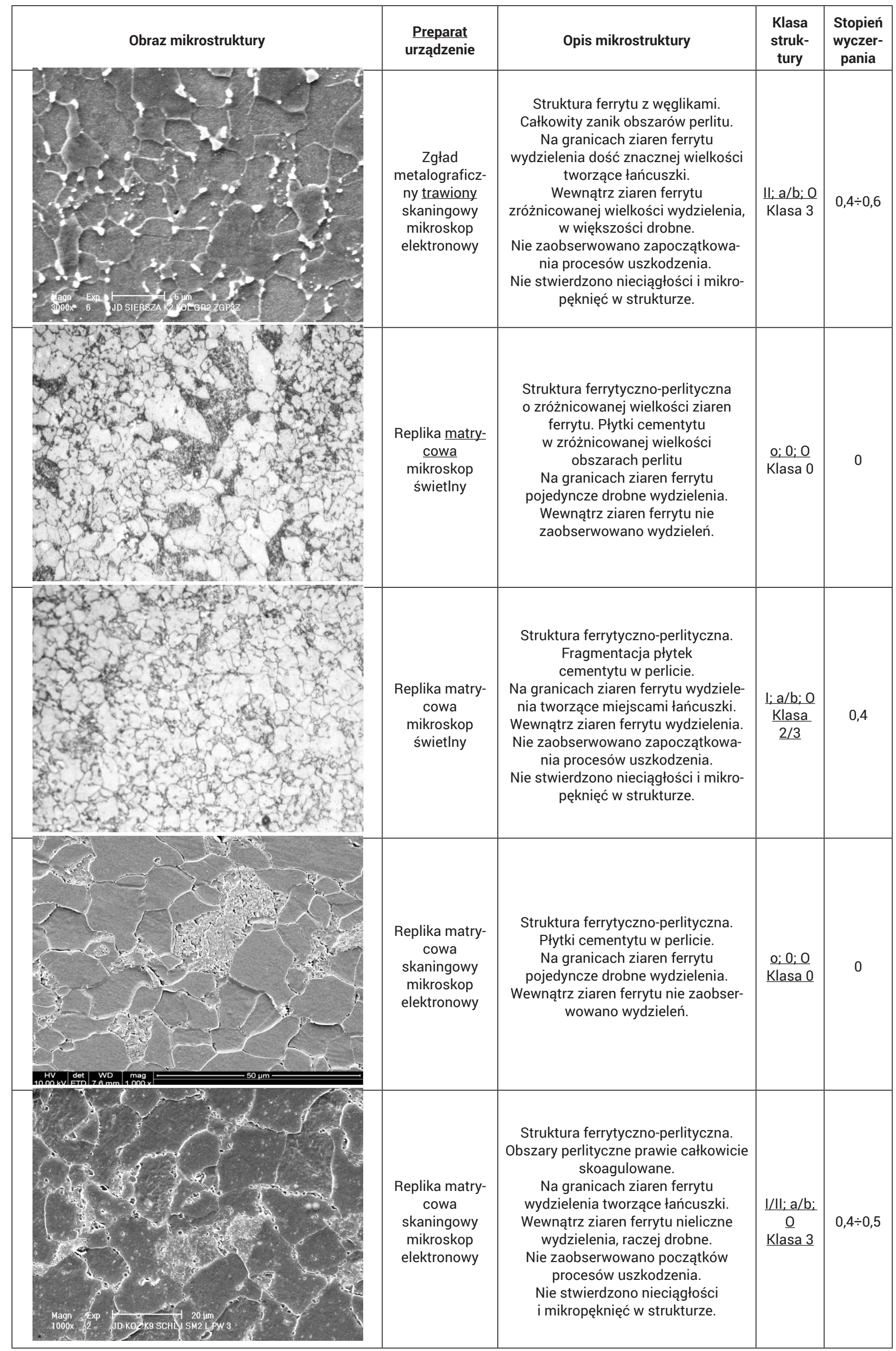




\section{Podsumowanie}

Eksploatacja stali energetycznych w warunkach podwyższonej temperatury i pełzania, prowadzi do degradacji mikrostruktury i wynikającego z niej obniżenia właściwości materiału. Osiągnięcie krytycznego pogorszenia właściwości materiału może być przyczyną awarii, a w konsekwencji znacznych strat nie tylko o charakterze materialnym. Trafność oceny stanu materiału oraz określenie stopnia wyczerpania jego możliwości w kontekście dalszej bezpiecznej eksploatacji jest niezwykle ważne z punktu widzenia dozoru i bezpieczeństwa technicznego. W zależności od zastosowanych metod badawczych, trafność oceny oraz prognoza dalszej bezpiecznej eksploatacji materiału może być niejednoznaczna bez znajomości charakterystycznych modeli degradacji mikrostruktury.

W ramach prowadzonych badań obserwowano kolejne stopnie degradacji mikrostruktury świadczące o stopniowym wyczerpywaniu się możliwości dalszej bezpiecznej eksploatacji. Zaproponowano sklasyfikowanie struktury oraz określenie stopnia wyczerpania na podstawie opisywanego postępu degradacji mikrostruktury.

Wyniki niniejszego opracowania mogą być przydatne:

- na potrzeby stawiania wymagań przygotowania niezbędnego programu oraz zakresu badań i metod oceny stanu materiału po długotrwałej eksploatacji. W rezultacie może służyć określeniu obiektywnej przydatności do dalszej eksploatacji elementów konstrukcyjnych, zarówno przed jak i po osiągnięciu obliczeniowego czasu pracy, a także w przypadku wystąpienia awarii związanej z nadmierną utratą trwałości eksploatacyjnej czy powstaniem nieciągłości materiału.

- w obszarze odpowiedzialności służb remontowych i utrzymania ruchu jednostek przemysłowych eksploatujących urządzenia ciśnieniowe pracujące w podwyższonej temperaturze,

- dla jednostek badawczych wykonujących diagnostyczne badania materiałowe, stanowi propozycję standardu odniesienia przy doborze racjonalnych metod badawczych i narzędzi do oceny stanu elementu oraz materiału i określania ich przydatności do dalszej eksploatacji.

Trwałość elementu konstrukcyjnego nie jest tożsama z trwałością materiału, z którego wykonano przedmiotowy element. Trwałość materiału (tzw. trwałość obliczeniowa) wyznaczana jest na podstawie czasowej wytrzymałości na pełzanie $\mathrm{R}_{\mathrm{z} / \mathrm{t} / \mathrm{T}} \mathrm{W}$ testach laboratoryjnych, które realizowane są przy jednoosiowym stanie naprężenia, $\mathrm{W}$ stabilnych warunkach temperatury, naprężenia i środowiska, na próbkach o modelowych cechach geometrycznych i stanie powierzchni. Jest to zatem wyidealizowane i znacząco uproszczone, ujęcie zagadnienia. W rzeczywistości element zazwyczaj poddany jest zmiennym obciążeniom i zmiennej temperaturze, może być nieregularnie wyłączany z ruchu i uruchomiany ponownie, środowisko pracy może być zmienne pod względem agresywności chemicznej, a stan powierzchni może być różny. Na trwałość elementu konstrukcyjnego wpływają również warunki transportu oraz kultura techniczna montażu i eksploatacji. Przywołane czynniki wskazują na konieczność prowadzenia diagnostyki materiałowej opartej na badaniach mikrostruktury, a metody obliczeniowe wykorzystujące stan wiedzy w zakresie charakterystyki materiału w stanie wyjściowym mają tylko charakter pomocniczy. Zastosowanie metod obliczeniowych powinno mieć wpływ na decyzję dotyczącą celowości podjęcia badań diagnostycznych oraz formułowania wymagań odnośnie zakresu i częstości ich przeprowadzania (czynnik ekonomiczny).

\section{Literatura}

[1] J. Dobrzański, A. Hernas: Sprawozdanie nr P/XII-2/2014 Zasady diagnostyki i oceny trwałości eksploatacyjnej elementów kotłów i rurociągów pracujących w warunkach pełzania - Etap I.

[2] J. Dobrzański, A. Hernas: Sprawozdanie nr P-2/III-1/2015 Zasady diagnostyki i oceny trwałości eksploatacyjnej elementów kotłów i rurociągów pracujących w warunkach pełzania - Etap II.

[3] Praca zbiorowa: Materiały Techniczne Urzędu Dozoru Technicznego nr 3/2013, Zasady diagnostyki i oceny trwałości eksploatacyjnej elementów kotłów i rurociągów pracujących w warunkach pełzania.

[4] Praca zbiorowa: Materiały stosowane w energetyce cieplnej, wyd. Politechniki Częstochowskiej, 2003.

[5] T. Chmielewski: Projektowanie procesów technologicznych - spawalnictwo Oficyna Wydawnicza Politechniki Warszawskiej, Warszawa, 2013.

[6] K. Ferenc, T. Chmielewski i inni: Technika spawalnicza w praktyce: poradnik inżyniera, konstruktora i spawacza, Verlag Dashofer, 2009.

[7] T. Sałaciński: SPC Statistical Process Control, Oficyna Wydawnicza Politechniki Warszawskiej, 2015.

[8] W Kramarek, T Sałaciński: Energetyka jądrowa na świecie (1), Przegląd Techniczny vol. 20, s. 13-19, 2013.
[9] P. Urbańczyk, J. Słania, G. Golański: Wpływ pełzania na uszkodzenia złącza spawanego rurociągu pary świeżej, Przegląd Spawalnictwa, vol. 86 (4), s. 23-30, 2014.

[10] M. Kwiecień, A. Głowacki: Pełzanie jako zjawisko ograniczające długotrwałą eksploatację rurociągów parowych, Energetyka, nr 7, s. 556-560, 2013.

[11] Soo Woo Nam: Assessment of damage and life prediction of austenitic stainless steel under high temperature creep-fatigue interaction conditio, Materials Science and Engineering: A, Vol. 322 (1-2), p. 64-72, 2002. http://dx.doi.org/10.1016/S0921-5093(01)01118-2

[12] Y. Takahashi: Study on creep-fatigue evaluation procedures for high-chromium steels - Part I: Test results and life prediction based on measured stress relaxation, International Journal of Pressure Vessels and Piping, vol. 85 (6), p. 406-422, 2008.

[13] R. Frith, M. Stone: A proposed new pressure vessel design class, International Journal of Pressure Vessels and Piping, vol. 139-140, p. 4-11, 2016.

[14] A. Ogrodnik, T. Chmielewski: Diagnostyka i ocena trwałości elementów kotła ze stali $16 \mathrm{Mo} 3$ pracującego w warunkach pełzania, Przegląd Spawalnictwa, vol. 89 (2), s. 37-43, 2017. 